\title{
MANAJEMEN KOMUNIKASI KELOMPOK INFORMASI MASYARAKAT KARANGPATIHAN DALAM MEMPERBAIKI CITRA DESA SEBAGAI KAMPUNG IDIOT
}

\author{
Tri Agustian Taufik \\ triagustiantaufiq999@gmail.com
}

\begin{abstract}
Abstrak. Desa Karangpatihan adalah salah satu desa yang dikenal sebagai kampung idiot di Ponorogo, karena sebagian masyarakatnya mengalami Tunagrahita. Padahal masyarakat yang mengalami tunagrahita sebesar 1,64\% dari jumlah penduduk. Desa Karangpatihan melakukan program untuk memperbaiki citra desa melalui organisasi Kelompok Informasi Masyarakat (KIM). Penelitian ini bertujuan untuk mengetahui bagaimana Manajemen Komunikasi KIM Desa Karangpatihan dalam memperbaiki citra Desa sebagai kampung idiot. Teori yang digunakan adalah empat tahap proses manajemen komunikasi menurut Scott M. Cutlip \& Alen H. Center. Metode penelitian yang digunakan deskriptif kualitatif. Pengumpulan data dilakukan dengan wawancara, observasi dan dokumentasi.

Hasil penelitian ini menunjukan bahwa KIM Karangpatihan Bangkit dalam memperbaiki citra desa sebagai kampung Idiot telah termanajemen. Temuan penelitian ini adalah 1. Batasan batasan masalah: memantau pemberitaan melalui media televisi, menemukan stigma negatif terkait Desa Karangpatihan. 2. Planning and programing: merencanakan program merubah kampung idiot menjadi kampung industri, mensurvei bahwa media sosial adalah media paling diminati. 3 . Pengambilan tindakan dan mengkomunikasikan dilakukan dengan pemberdayaan masyarakat keterbelakangan mental, pemilihan bahasa Indonesia dalam penyampaian pesan, mensosialisasikan kegiatan desa Karangpatihan menggunakan facebook, instagram, memberitakan kegiatan melalui website, menjalin relasi dengan karangtaruna setiap dukuh. 4. Evaluasi dilakukan dengan menerima penghargaan dari presiden. Hasil analisis menunjukkan bahwa KIM telah melakukan kegiatan yang sejalan dengan teori manajamen komunikasi, namun belum sepenuhnya termanajemen. KIM Karangpatihan melakukan penyebaran informasi terkait desa melalui media sosial sedangkan KIM Karangpatihan mengetahui desa Karangpatihan sebagai kampung idiot melalui media televisi dan evaluasi hanya sebatas menerima penghargaan tetapi belum mengukur ketercapaian program.
\end{abstract}

Kata kunci: Manajemen Komunikasi, Citra, Kampung Idiot, Kelompok Informasi Masyarakat

\footnotetext{
Abstract. Karangpatihan village is one of the villages known as an idiot village in Ponorogo, because some of its people are mentally retarded. Even though people who experience mental retardation are $1.64 \%$ of the total population. Karangpatihan Village carried out a program to improve the image of the village through the Community Information Group (KIM) organization. This study aims to see how the Communication Management of KIM Desa Karangpatihan in improving the image of the village as an idiot village. The theory used is a four-stage communication management process according to Scott M. Cutlip \& Alen H. Center. The research method used is descriptive qualitative. Data collection was carried out by interview, observation and documentation.
} 
The results of this study indicate that KIM Karangpatihan Bangkit has managed to improve the image of the village as an Idiot village. The findings of this study are 1. Boundary constraints of the problem: observation of news through television media, finding the stigma associated with Karangpatihan Village. 2. Planning and programming: Planning a program to turn an idiot village into an industrial village, stating that social media is the most popular media. 3. Taking action and communicating is carried out by empowering the mentally retarded community, selecting Indonesian language in delivering messages, socializing Karangpatihan village activities using Facebook, Instagram, reporting activities through the website, establishing relationships with Karangtaruna in each hamlet. 4. Evaluation is carried out by receiving an award from the president. The results of the analysis show that KIM has carried out activities that are in line with management theory, but have not been managed. KIM Karangpatihan conducts information dissemination related to the village through social media, while KIM Karangpatihan supervises Karangpatihan village as an idiot village through evaluation media only to receive awards but not yet measure program achievement.

Keywords: Communication Management, Image, Idiot Village, Community Information Group

\section{PENDAHULUAN}

Ponorogo adalah salah satu daerah yang memiliki beberapa desa yang dikenal dengan sebutan Kampung Idiot, hal itu diketahui karena adanya beberapa desa yang memiliki penduduk tunagrahita yaitu desa Pandak, desa Jambon, dan desa Karangpatihan. Salah satu desa yang memiliki keinginan untuk menghapus label tersebut adalah desa Karangpatihan dengan membentuk Kelompok Informasi Masyarakat. Kelompok tersebut menyaring semua informasi terkait desa Karangpatihan, adapun kegiatan kelompok informasi masyarakat ini diantaranya membuat sebuah kerajinan batik ciprat dan peternakan untuk para penderita tunagrahita, dengan tujuan untuk menghilangkan label sebutan sebagai Kampung Idiot menjadi kampung mandiri. Sepertihalnya dalam penelitian Muhammad Resqi yang berjudul Strategi komunikasi pemerintahan kabupaten ponorogo dalam meningkatkan sosialisasi masyarakat melalui kelompok informasi masyarakat (KIM). Dalam penelitian tersebut dijelaskan bahwasannya desa Karangpatihan termasuk salah satu desa yang memiliki kelompok informasi masyarakat (KIM), sehingga dapat diketahui bahwasannya desa Karangpatihan ingin bangkit dari sebutan Kampung Idiot sehingga membentuk KIM tersebut ${ }^{1}$.

\footnotetext{
${ }^{1}$ Muhammad Resqi, "Strategi Komunikasi Pemerintahan Kabupaten Ponorogo Dalam Meningkatkan Sosialisasi Masyarakat Melalui Kelompok Informasi Masyarakat” (Universitas Darussalam Gontor, 2020).
} 
Desa Karangpatihan adalah salah satu desa yang terletak di Kecamatan Balong Kabupaten Ponorogo yang berjumlah penduduknya 5.843 jiwa dari 1.463 Kepala Keluarga. Masyarakat luas memberikan sebutan unik untuk desa Karangpatihan yakni "Kampung Idiot". Hal ini terjadi karena sebagian dari warganya memiliki kekurangan fisik (tunagrahita). sebanyak 96 jiwa dari 63 Kepala Keluarga di empat Dukuh yang berada di Karangpatihan mengalami keterbelakangan mental (tunagrahita). Adapun pemberitaan dimedia yang menyebut desa Karangpatihan sebagai Kampung Idiot diberitakan oleh Surabaya.tribunnews.com sebagai berikut:

"Surya online, Ponorogo. Kasus Kampung Idiot di wilayah Kabupaten Ponorogo seakan tak pernah ada habisnya. Buktinya paska Kampung Idiot di Desa Sidowayah dan Desa Sidoharjo, Kecamatan Jambon (Kampung Idiot Jilid 1) mencuat. kemudian muncul Kampung Idiot Jilid 2 yang berada di Desa Karangpatihan Kecamatan Balong, disusul kembali Kampung Idiot Jilid 3 yakni Desa Pendak Kecamatan Balong2."

Dalam pemberitaan diatas sangat jelas disebutkan bahwa Kabupaten Ponorogo salah satu daerah yang memiliki beberapa desa yang dikenal dengan sebutan Kampung Idiot dan menyebabkan timbulnya citra kurang baik di Jawa Timur. Salah satu desa yang disebut Kampung Idiot adalah desa Karangpatihan.

Dapat diketahui bahwasannya desa Karangpatihan adalah salah satu desa yang memiliki sebuah keunggulan dari desa idiot lainnya seperti desa pandak dan jambon, karena desa Karangpatihan pada tahun 2020 mendapatkan sebuah piagam penghargaan oleh Badan Pembinaan Ideologi Pancasila karena dapat memberdayakan masyarakat tunagrahita, sehingga membuat sebutan kampung idiot menjadi kampung indutri serta diberikan langsung penghargaan tersebut oleh tokoh-tokoh nasional yaitu ibu Susi Puji Astuti.

\section{Kajian Pustaka}

Manajemen komunikasi merupakan suatu proses yang bertujuan untuk mencapai suatu tujuan dengan cara efektif serta efisien dan menggunakan sumber daya yang telah ada. Manajemen berasal dari kata kerja "manage" yang berarti mengemudikan, mengurus, serta memerintah ${ }^{3}$. Sedangkan dalam kamus bahasa francis "manage" memiliki arti sebagai suatu tindakan, membimbing dan memimpin4.

Menurut Michel kaye bahwasannya manajemen komunikasi adalah bagaimana individu atau kelompok manusia dalam mengelola suatu proses komunikasi dengan cara

\footnotetext{
2 sudarmawan, "Sekampung 34 Jiwa Mengalami Keterbelakangan Mental," Surabaya tribunnews, 2013.

3 Poerwadarminta Dojowarsito, Kamus Lengkap Indonesia-Inggris, ed. Hasta (Jakarta, 1974).

4 Yusuf Zainal Abidin, Manajemen Komunikasi (Bandung: CV Pustaka Setia, 2015).
} 
menyusun suatu kerangkan makna dalam melakukan suatu hubungan dengan orang lain dalam berbagai konteks komunikasi dengan mengoptimalkan sumberdaya dan teknologi yang sudah ada 5 .

Menurut Parag Diwan bahwasannya manajemen komunikasi adalah suatu proses pemanfaatan sumberdaya komunikasi yang ada dengan cara terpadu dan melalui sebuah proses perencanaan, pelaksanaan, pengorganisasian serta pengontrolan unsur-unsur komunikasi agar tercapainya suatu tujuan yang telah ditetapkan6.

Sedangkan menurut Irwin dan More berpendapat bahwasnnya manajemen komunikasi adalah suatu proses dalam memanfaatkan sumber daya manusia, keuangan dan teknis serta memahami dan menjalankan fungsi komunikasi dalam perusahaan atau intansi, antara perusahaan dan publiknya. Maka dari itu manajemen komunikasi melibatkan pengelolaan sumber daya komunikasi (pribadi, kelompok, organisasi dan teknis) dan proses komunikasi untuk memfasilitasi komunikasi dalam konteks perusahaan?

Dari beberapa kutipan diatas dapat disimpulkan bahwasannya manajemen komunikasi adalah bagaimana seseorang atau organisasi dalam mengelola proses komunikasi dengan menggunakan kontruksi makna perihal suatu hubungan yang baik dengan orang lain dalam keadaan yang beragam serta memberikan arahan terhadap orang lain dalam bekerja dengan konteks komunikasi secara efektif, efisien dan produktif.

Bila ditinjau dari islamisasi ilmu pengetahuan menunjukan bahwasannya islam telah meletakkan dasar-dasar manajemen dalam mengatur kehidupan masyarakat. Hal ini dijelaskan dalam Al-Qur'an surat Yunus ayat 3 yang berbunyi:

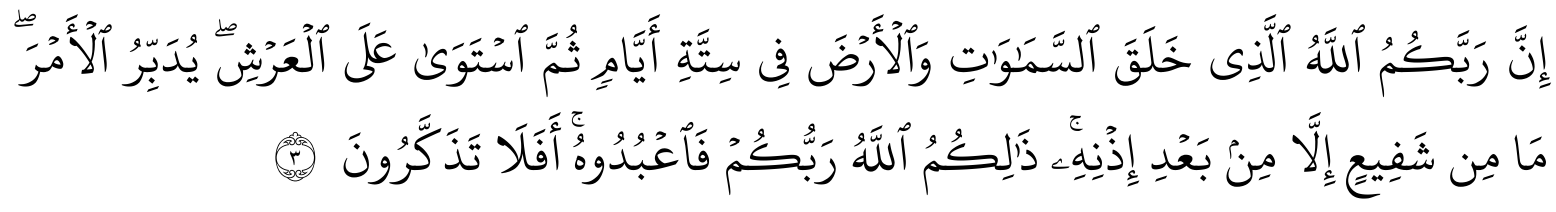

Artinya:

Sesungguhnya Tuhan kamu ialah Allah yang menciptakan langit dan bumi dalam enam masa. Kemudian dia bersemayan diatas 'Arsy untuk mengatur segala urusan. Tiada seorang pun yang akan memberi syafa'at kecuali sesudah ada izin-Nya. (Dzat) yang demikian itulah Allah, Tuhan kamu, maka sembahlah dia. Maka apakah kamu tidak mengambil pelajaran?

Dalam penafsiran tafsir jalalayn (sesungguhnya Rabb kalian ialah Allah yang telah menciptakan langit dan bumi dalam enam hari) dari hari-hari dunia, dan dapat diartikan

\footnotetext{
5 Micheal kaye, Communication Management (Australia: Pretince Hall, 1994).

${ }^{6}$ Diwan Parag, Communication Management (Kuala Lumpur: Golden Books, 1999). 1994).

${ }^{7}$ Harry Irwin, Managing Corporate Communication (Malaysia: Allen \& Unwin Business and Management,
} 
dalam masa yang perkiraannya sama dengan enam hari, karena didalam masa tersebut belum adanya matahari dan bulan. Akan tetapi jika Allah telah berkehendak maka dengan sekejap Allah dapat menciptakannya. Akan tetapi Allah tidak melakukan dengan cara tersebut karena Allah ingin memberikan sebuah pelajaran kepada makhluknya tentang ketekunan dan kesabaran dalam bertindak (kemudian dia bersemayan di atas 'Arsy) dengan sifatnya yang agung maka Allah bersemayan di atas 'Arsy (untuk mengatur segala urusan) untuk mengatur makhluk-makhluknya (tiada seorang pun) huruf min merupakan kata shilah atau penghubung (yang dapat memberikan syafaat) kepada makhluk-makhluknya (kecuali sesudah ada keizinan-Nya) ayat ini merupakan sanggahan terhadap perkataan orang-orang kafir yang menyatakan bahwa berhala-berhala mereka dapat memberikan syafaat kepada diri mereka. (Zat yang demikian itulah) yaitu yang menciptakan dan yang mengatur (Allah, Rabb kalian, maka sembahlah Dia) artinya tauhidkanlah Dia. (Maka apakah kalian tidak mengambil pelajaran?) lafal tadzakkaruuna asalnya tatadzakkaruuna, kemudian huruf ta yang kedua diidgamkan ke dalam huruf dzal asal kalimat, maka jadilah tadzakkaruuna ${ }^{8}$.

Berdasarkan pernyataan diatas dapat disimpulkan bahwasannya disetiap pekerjaan seseorang harus memiliki sebuah perencaaan sebelum melakukan suatu kegiatan agar dapat mencapai terhadap tujuan utama, maka dari itu suatu kegiatan atau pekerjaan yang baik harus didasari dengan prinsip-prinsip manajemen yang baik diantaranya yaitu: perencanaan, pengorganisasian, pelaksanaan dan pengawasan serta evaluasi.

Selain itu Cutlip, Center \& Broom berpendapat bahwasannya dalam memecahkan suatu masalah komunikasi yang efektif dan efisien menggunakan empat langkah manajemen komunikasi secara oprasional diantaranya seperti:

\section{Batasan-Batasan Masalah}

Tahap ini menjelaskan untuk mengkaji dan memantau suatu opini serta perilaku yang berkaitan dengan suatu kebijakan organisasi. Selain itu tahapan ini memberikan suatu tahapan untuk menyelesaikan suatu masalah yang timbul.

\section{Perencanaan dan Program.}

Perencanaan adalah sebuah strategi dalam menentukan serangkaian tindakan agar tercapainya hasil yang diharapkan. Selain itu juga perencanaan merupakan sebuah penetapan tentang sesuatu yang ingin dicapai, dimana hal itu dicapai, siapa yang bertanggung

\footnotetext{
${ }^{8}$ Imam Asy-Syafi'i, Tafsir Jalalain (Jakarta: Pustaka Imam Asy-syafi'i, 2008).

${ }_{9}^{9}$ Scott M Cutlip, Effective Public Relations Edisi Kesembilan (Jakarta: Kencana, 2011).
} 
jawab, bagaimana hal itu harus dicapai, dan penetapan hal itu harus dicapai ${ }^{10}$. Maka dari itu pada tahapan perencanaan dalam penelitian ini akan lebih fokus pada pengumpulan informasi pada tahapan pertama bertujuan untuk membuat suatu keputusan tentang publik program, tujuan, tindakan, serta merancang taktik yang bertujuan untuk mewujudkan kedalam suatu kebijakan dan program organisasi. Perencanaan merupakan syarat mutlak bagi setiap kegiantan manajemen komunikasi, tanpa adanya suatu perencanaan maka kegiatan tersebut akan tidak berjalan dengan baik bahkan mengalami kegagalan ${ }^{11}$.

\section{Pengambilan Suatu Tindakan dan Mengkomunikasikannya.}

Dalam tahapan ini untuk mewujudkan suatu tindakan program komunikasi yang dirancang untuk mencapai tujuan spesifik bagi setiap publik demi mencapai tujuan program

\section{Evaluasi Program.}

Tahapan ini mencakup penilaian persiapan, pelaksanaan, dan hasil program. Saat program sedang dilaksanakan, dibuat penyesuaian umpan balik tentang bagaimana program berjalan atau tidak berjalan. Pada umumnya hubungan manajemen komunikasi terhadap pubik dapat dibagi menjadi dua yaitu: pubik internal dan publik eksternal, publik internal yang terdiri dari orang yang ada didalamnya. Sedangkan publik eksternal yang terdiri dari khalayak sekitar, pemerintah dan perss ${ }^{12}$.

Penelitian tentang Strategi Humas dalam memperbaiki citra pernah dilakukan oleh Khafidz Raka Raditya dengan judul Strategi Humas PT Pupuk Sriwidjaja Dalam Melakukan Kegiatan Media Gathering. Hasil penelitian ini menunjukan bahwa praktisi public relation PT Pupuk Sriwidjaja melakukan strategi four step Publik Relation secara sistematis tersusun dengan rapih serta mencapai tujuan utama intansi. Adapun perbedaan penelitian ini dengan penelitian saya yaitu penelitian ini adalah salah satu penelitian dalam hal objek kajian, yang mana penelitian ini difokuskan pada media gathering. Sedangkan penelitian saya lebih fokus terhadap masyarakat luas dan media sosial dan penelitian saya bertempatan di desa Karangpatihan dan penelitian ini bertempatan di PT.Pupuk Sriwidjaja ${ }^{13}$.

\footnotetext{
${ }^{10}$ Rindyah Hanafi Amriullah, Pengantar Manajemen (Yogyakarta: Graha Ilmu, 2002).

11 Husaini Utsman, Manajemen Teori, Praktik, Dan Riset Pendidikan (Jakarta: Bumi Aksara, 2009).

12 Effendi Uchjana Onong, Humas Relation \& Public Relation (Jakarta: Gramedia, 1993).

13 Khafidz Raka Raditya, "Strategi Humas Pt Pupuk Sriwidjaja Dalam Melakukan Kegiatan Media Gatehring (Studi Pada Penanganan Isu Kelangkaan Pupuk Urea Bersubsidi Di Daerah Lampung, Jawa Tengah Dan, Yogyakarta Pada Tahun 2018)" (Sriwijaya, 2018),Https://Repository.Unsri.Ac.Id/27308/2.
} 


\section{METODE PENELITIAN}

Metode yang digunakan dalam penelitian ini adalah metode penelitian kualitatif, menurut Sugiono metode penelitian kualitatif disebut dengan metode penelitian naturalistik karena penelitian ini dilakukan dengan senatural mungkin (alamiah) karena semua data-data yang terkumpul serta analisisnya bersifat kualitatif 14 .

Obyek penelitian adalah sebuah himpunan elemen yang dapat berupa orang, tempat, barang, dan organisasi yang akan diteliti atau sebuah pokok persoalan yang akan diteliti untuk mendapatkan data yang benar ${ }^{15}$. Adapun obyek dalam penelitian ini yaitu manajemen komunikasi kelompok informasi masyarakat karangpatihan bangkit dalam memperbaiki citra desa Karangpatihan.

Lokasi penelitian adalah tempat melakukan kegiatan untuk memperoleh data yang berasal dar responden. lokasi penelitian ini bertempatan di desa Karangpatihan, kecamatan Balong, kabupaten Ponorogo.

Informan dalam penelitian ini penulis menggunakan teknik sampling Purposive sampling, Purposive sampling adalah teknik pengambilan sampel dengan menentukan kriteria-kriteria yang mendukung tujuan dari penelitian ${ }^{16}$. Berdasarkan uraian diatas, maka informan dalam penelitian ini adalah sebagai berikut: Kepala desa Karangpatihan Bapak Eko Mulyadi selaku dewan penasehat KIM Karangpatihan, Ibu Ambar selaku ketua KIM Karangpatihan, Bapak Teguh Prasetyo selaku ketua Teknik Informasi KIM, dan Mas Muhammad Ilham Fadhillah selaku anggota Teknik Informasi KIM.

Teknik pengumpulan data merupakan bagaimana caranya mengumpulkan data, menghimpun, mengambil, serta menyaring data penelitian yang berada dilapangan. Peneliti menggunakan tiga teknik pengumpulan data antara lain: Teknik Wawancara, Teknik Observasi, dan Teknik Dokumentasi.

Wawancara adalah sebuah percakapan yang memiliki sebuah maksud tertentu, yang mana diakukan oleh dua pihak antara lain pewawancara yang memiliki tugas untuk mengajukan sebuah pertanyaan. Terwawancara yang mana sebagai orang yang memberikan jawaban atas pertanyaan yang dianturkan oleh pewawancara ${ }^{17}$.

\footnotetext{
14 Sugiyono, Memahami Penelitian Kualitatif (Bandung: Alphabet, 2014).

15 J Supranto, Statistik Teori Dan Aplikasi, 1st ed. (Jakarta: Erlangga, 2000).

16 Rachmat Kriyantono, Teknik Pratis Riset Komunikasi (Jakarta: Kencana Prenada Media, 2016).

17 Lexy J. Moleong, Metodologi Penelitian Kualitatif (Edisi Revisi), PT. Remaja Rosda Karya (Bandung: PT.Remaja Rosdakarya, 2017).
} 
Observasi adalah teknik pengumpulan data yang ditentukan oleh peneliti dengan pengamatannya sendiri, sebab didalam observasi peneliti harus meneliti secara langsung objeknya dan kemudian menyimpulkan apa yang diamati ${ }^{18}$.

Dokumentasi adalah catatan tertulis atau rekaman yang sengaja dipersiapkan ataupun tidak dipersiapkan yang berhubungan dengan suatu peristiwa masa lalu yang berbentuk memo, diary, pengumuman, surat, foto, video, film, dan lain-lain. Dari sini peneliti mencari dan memanfaatkan catatan tertulis atau dokumentasi yang dimiliki desa Karangpatihan. Hal ini untuk menunjang kelengkapan data pada penelitian ini. Dokumentasi yang diperoleh pada penelitian ini adalah sejarah desa Karangpatihan, Visi, Misi, foto pelatihan batik ciprat, serta dokumentasi desa Karangpatihan ${ }^{19}$.

\section{Teknik anaisis data}

Triangulasi data pada hakikatnya merupakan pendekatan multimetode yang dilakukan peneliti pada saat mengumpulkan dan menganalisis data. Ide dasarnya adalah bahwa fenomena yang diteliti dapat dipahami dengan baik sehimgga diperoleh kebenaran tingkat tinggi jika didekati dari berbagai sudut pandang. Triangulasi meliputi tiga hal,yaitu ${ }^{20}$ : Triangulasi Metode, Triangulasi Sumber Data, Triangulasi Teori. Dalam penelitian ini keabsahan data dilakukan dengan cara triangulasi sumber data dan triangulasi metode.

Triangulasi Sumber Data Menggali kebenaran data atau inforasi melalui berbagai sumber data yang berbeda. Misalnya selain memanfaatkan data dari wawancara dan observasi, peneliti juga dapat menggunakan observasi yang telah terlibat (participant observation), dokumen tertulis, dokumen sejarah, arsip, catatan resi, tulisan pribadi serta gambar atau foto 21.

Triangulasi Metode Triangulasi metode adalah sebuah metode untuk mengecek keabsahan sebuah data serta mengecek temuan peneliti. Triangulasi metode dilakukan dengan cara membandingkan sebuah informasi atau data dengan menggunakan metode yang berbeda. Misalnya membandingkan sebuah data yang diperoleh melalui interview dengan data observasi. Selain itu membandingkan sebuah data argumentasi penulis dengan data semi dari peneliti lainnya ${ }^{22}$.

\footnotetext{
18 Rachmat Kriyantono, Teknik Praktis Riset Komunikasi (Jakarta: Erlangga, 2007).

${ }^{19}$ Sugiyono, Metode Penelitian Kombinasi (Bandung: Alphabet, 2017).

20 Sugeng Pujileksono, Metode Penelitian Komunikasi Kualitatif (Malang: Intrans Publishing, 2016).

21 Kriyantono, Teknik Praktis Riset Komunikasi, 2007.

22 Rachmat Kriyantono, Teknik Praktis Riset Komunikasi (Jakarta: Kencana Prenada Media, 2016).
} 


\section{HASIL DAN PEMBAHASAN}

Desa Karangpatihan adalah salah satu desa yang berada di kecamatan Balong kabupaten Ponorogo, desa ini adalah sebuah desa yang memiliki sebuah citra yang kurang baik karena ada sebutan sebagai kampung idiot dalam desa Karangpatihan sendiri, maka dari itu kepala desa karangpatihan memiliki sebuah program untuk mendirikan kelompok informasi masyarakat yang bertugas untuk memperbaiki citra bagi desa tersebut. Selain itu kelompok informasi masyarakat memiliki sebuat strategi untuk memperbaiki citra desa Karangpatihan dengan menggunakan empat tahap manajemen komunikasi.

\section{Mendefinisikan Masalah}

Dalam perspektif manajemen komunikasi dilakukan dengan mengkaji dan memantau sebuah fenomena serta perilaku yang sedang terjadi khususnya dalam sebuah citra desa terutama pada desa Karangpatihan, agar dapat mengetahui tentang sebuah program kedepannya agar dapat memperbaiki sebuah citra dan tidakan kepada permasalahanpermasalahan yang lainnya, sedangkan fokus permasalahan peneliti saat ini kepada manajemen komunikasi dalam memperbaiki citra desa. Berdasarkan dari hasil penelitian peneliti dalam wawancara bahwasannya Kelompok Informasi Masyarakat desa Karangpatihan memantau sebuat opini terkait desa melalui media massa sepertihalnya pemberitaan melalui televise, hal ini di perkuat dari hasil wawancara dengan kepala desa selaku dewan penasehat dalam organisasi KIM yaitu:

"Jadi sebutan kampung idiot ini terjadi pada tahun 2007-2008 waktu itu ada salah satu media TV nasional memberitakan tentang desa Karangpatihan dan kami sangat mengapresiasikan itu karena dengan adanya berita tersebut kita dapat perhatian langsung oleh pemerintah daerah maupun publik sehingga pemerintah datang kesini untuk mensurvei keadaan dan kami menerimanya dengan senang hati karena memang pada tahun tersebut kondisinya seperti itu"23.

Dalam hasil wawancara dengan bapak kepala desa selaku dewan penasehat Kelompok Informasi Masyarakat dapat kita ketahui bahwasannya mereka melihat dan memantau tentang desa Karangpatihan menggunakan media massa berupa televise, akan tetapi dari pemberitaan melalui televise bahwasannya memiliki sebuah citra yang negatif selain itu juga mereka memiliki sebuah peluang yang besar dalam meperbaiki citra desanya dengan adanya perhatian khusus oleh pemerintahan secara langsung, sehingga dapat

${ }^{23}$ Mulyadi, Eko. Dewan Penasehat Kelompok Informasi Masyarakat Karangpatihan Bangkit, Jum'at 30 Oktober 2020 pagi jam 07.30 wib. 
membuat desa Karangpatihan ini maju dan tidak tertinggal lagi. kedua penentuan batasanbatasan masalah dengan munculnya stigma negatif ditengah masyarakat sekitar sepertihalnya yang dirasakan oleh para pemuda-pemuda desa Karangpatihan ketika sedang berada di daerah sekitar merekan mendapatkan sebuah stigma negatif oleh masyarakat lainnya.

\section{Perencanaan dan Program}

Didalam indikator kedua ini perlu adanya sebuah program yang dirancang secara mendasar, sepertihalnya kita harus mengetahui apa maksud dan tujuan dari program kita ini, bagaimana tentang audience yang akan kita tuju, pokok ide pesan apa yang akan kita gunakan dan dapat membuat audience kita tertarik untuk melihat, dan kita juga harus mengetahui tentang media yang audience lebih gunakan agar program kita ini dapat tersampaikan kepada audience. Berdasarkan dari hasil penelitian peneliti dalam wawancara bahwasannya Kelompok Informasi Masyarakat desa Karangpatihan merancanakan program untuk merubah kampung idiot menjadi kampung industry, Mensurvei bahwa media sosial adalah media yang paling diminati.

\section{Pengambilan Tindakan dan Mengkomunikasikannya}

Dalam tahapan ini bertujuan untuk mewujudkan suatu tindakan program komunikasi yang telah dirancang sebelumnya untuk mencapai sebuah feedback yang baik bagi setiap publik, dan dalam tahapan ini menurut Cutlip Center dan Broom memiliki 3 hal terpenting yang dikemukakan diantaranya yaitu: The Action Component Of Strategi (strategi aksi), didalam tahapan proses manajemen komunikasi harus dapat melakukan sebuah tindakan yang bersifat Acting Responsively and Responsibly artinya proses manajemen komunikasi harus dapat mendengar keinginan publik dan harus bertanggung jawab atas program tersebut, The Communication Component of Strategy (strategi komponen kominikasi), seorang manajemen komunikasi disini harus dapat berkonsentrasi terhadap pengkomunikasiannya, mulai dari mempertimbangkan penggunaan media, sumber media, bagaimana membawa komunikan atau sasarannya kearah yang diinginkan, memodifikasi sebuah pesan agar dapat menggiring opini serta sikap perilaku publik, Implementing the strategy (implementasi strategi manajemen komunikasi).

Sehingga KIM Karangpatihan Bangkit melakukan sebuah program dengan pemberdayaan masyarakat Tungrahita dalam pelatihan pembuatan batik agar dapat merubah psebuah pandangan negatif menjadi pandangan positif untuk desa Karangpatihan selain itu agar masyarakat yang mengalami tunagrahita memiliki kemandirian dalam 
hidupnya dan tidak lagi berketergantungan dengan orang lain, Menyelengarakan event bertujuan agar banyak masyarakat sekitar berkunjung ke desa Karangpatihan secara langsung dan melihat situasi dan kondisinya, pemilihan bahasa indonesia dalam penyampaian pesan yang bertujuan untuk memberitahukan sebuah informasi terkait masyarakat yang luas karena bahasa Indonesia adalah bahasa yang mudah dipahami oleh masyarakat luas, mensosialisasikan kegiatan Karangpatihan menggunakan facebook, instagram, twitter, Selain itu KIM Karangpatihan Bangkit juga memberitakan kegiatan melalui website, dan menjalin relasi dengan karangtaruna disetiap dukuh.

\section{Mengevaluasi Program}

Langkah terakhir dalam teori Cuthlip \& Center adalah melakukan sebuah penilaian atas implementasi, persiapan dan hasil dari program tersebut. Penyesuaian akan dilakukan saat saat program yang telah dibuat dijalankan dan didasarkan dengan evaluasi atas umpan balik bagaimana program tersebut sudah berjalan atau belum. Evaluasi program yang dilakukan oleh KIM Karangpatihan bangkit seperti halnya mengadakan sebuah event perkumpulan dengan dewan pengarah seminggu satu kali dan Kelompok Informasi Masyarakat Karangpatihan Bangkit hanya melakukan sebuah evaluasi program dengan cara perolehan sebuah penghargaan saja tidak melakukan sebuah evaluasi secara meluas tentang program dan perencanaan. Sehingga dapat diketahui bahwasannya KIM Karangpatihan Bangkit belum melakukan Evaluasi sesuai dengan teori Cutlip \& Center.

\section{PENUTUP}

\section{Kesimpulan}

Berdasarkan hasill penelitian dan analisis dapat disimpulkan bahwa KIM Karangpatihan Bangkit melakukan upaya atau program untuk mengubah sebutan kampung idiot menjadi kampung industri telah sejalan dengan empat tahapan proses manajemen komunikasi meskipun terdapat beberapa kegiatan manajemen komunikasi yang belum sepenuhnya sejalan dengan teori seperti halnya pengambilan tindakan dan mengkomunikasikan dalam indikator ini diketahui bahwasannya kelompok informasi masyarakat Karangpatihan telah melakukan sebuah penyebaran informasi melalui sosial media akan tetapi dalam batasan masalah diketahui bahwasannya kelompok informasi masyarakat Karangpatihan mengetahui desa karangpatihan sebagai kampung idiot melalui media mainstream serta dalam melakukan evaluasi diketahui bahwasannya Kelompok 
Informasi Masyarakat Karangpatihan melakukan evaluasi dengan menggunakan sebuah penghargaan bukan sesuai dengan tahapan proses manajemen komunikasi.

1. Batasan-batasan permasalahan, dalam tahapan ini dapat diketahui bahwasannya KIM Karangpatihan Bangkit telah melakukan sebuah pemantauan terkait fenomenafenomena yang ada di desa Karangpatihan pada media massa berupa Televisi. Selain itu juga KIM Karangpatihan Bangkit mengetahui tentang fenomena yang ada terkait desanya melalui stigma negatif yang dialami masyarakatnya ketika berpegian ketempat lainnya.

2. Perencanaan dan program, didalam tahapan ini dapat diketahui bahwasannya KIM Karangpatihan Bangkit membuat sebuah perencanaan yang memiliki sebuah tujuan yakni dengan cara merencanakan perubahan sebutan desa Karangpatihan sebagai Kampung Idiot menjadi kampung industri dan melakukan survey terkait media yang paling sering digunakan masyarakat.

3. Pengambilan tindakan dan mengkomunikasikannya, didalam tahapan ini dapat diketahui bahwasannya KIM Karangpatihan Bangkit melakukan program sebagai berikut: Pemberdayaan Masyarakat yang mengalami Keterbelakangan Mental dengan pelatihan pembuatan batik ciptrat, Proses Pemilihan Bahasa Indonesia Dalam Penyampaian Pesan, Melakukan penyebaran informasi terkait desa karangpatihan dengan menggunakan media sosial facebook, Instagram, twitter dan youtube, Mengadakan sebuah event besar tekait desa Karangpatihan, Menjalin hubungan baik dengan karangtaruna disetiap dukuh.

4. Mengevaluasi Program, didalam tahapan ini dapat diketahui bahwasannya KIM Karangpatihan Bangkit melakukan sebuah evaluasi terkait program yang ada, selain itu KIM Karangpatihan Bangkit melakukan sebuah pemantauan terkait program yang telah dibuat. 


\section{DAFTAR PUSTAKA}

Abidin, Yusuf Zainal. Manajemen Komunikasi: Filosofi, Konsep Dan Aplikasi. Bandung: Pustaka Setia, 2015.

Abidin, Yusuf Zainal. Manajemen Komunikasi. Bandung: CV Pustaka Setia, 2015.

Amriullah, Rindyah Hanafi. Pengantar Manajemen. Yogyakarta: Graha Ilmu, 2002.

Asy-Syafi'i, Imam. Tafsir Jalalain. Jakarta: Pustaka Imam Asy-syafi'i, 2008.

Cutlip, Scott M. Effective Public Relations Edisi Kesembilan. Jakarta: Kencana, 2011.

Dojowarsito, Poerwadarminta. Kamus Lengkap Indonesia-Inggris. Edited by Hasta. Jakarta, 1974.

Irwin, Harry. Managing Corporate Communication. Malaysia: Allen \& Unwin Business and Management, 1994.

kaye, Micheal. Communication Management. Australia: Pretince Hall, 1994.

Kriyantono, Rachmat. Teknik Praktis Riset Komunikasi. Jakarta: Erlangga, 2007.

_—_. Teknik Praktis Riset Komunikasi. Jakarta: Kencana Prenada Media, 2016.

_—_. Teknik Pratis Riset Komunikasi. Jakarta: Kencana Prenada Media, 2016.

Moleong, Lexy J. Metodologi Penelitian Kualitatif (Edisi Revisi). PT. Remaja Rosda Karya. Bandung: PT.Remaja Rosdakarya, 2017.

Parag, Diwan. Communication Management. Kuala Lumpur: Golden Books, 1999.

Pujileksono, Sugeng. Metode Penelitian Komunikasi Kualitatif. Malang: Intrans Publishing, 2016.

Raditya, khafidz raka. "strategi humas pt pupuk sriwidjaja dalam melakukan kegiatan media gatehring (studi pada penanganan isu kelangkaan pupuk urea bersubsidi di daerah lampung, jawa tengah dan, yogyakarta pada tahun 2018)." Sriwijaya, 2018. Https://repository.unsri.ac.id/27308/2/rama_70201_07031381320017_0024126003_ 0014059002_01_front_ref.pdf.

Resqi, Muhammad. "Strategi Komunikasi Pemerintahan Kabupaten Ponorogo Dalam Meningkatkan Sosialisasi Masyarakat Melalui Kelompok Informasi Masyarakat." Universitas Darussalam Gontor, 2020.

sudarmawan. "Sekampung 34 Jiwa Mengalami Keterbelakangan Mental." Surabaya tribunnews, 2013.

Sugiyono. Memahami Penelitian Kualitatif. Bandung: Alphabet, 2014.

_-_. Metode Penelitian Kombinasi. Bandung: Alphabet, 2017.

Supranto, J. Statistik Teori Dan Aplikasi. 1st ed. Jakarta: Erlangga, 2000.

Uchjana Onong, Effendi. Humas Relation \& Public Relation. Jakarta: Gramedia, 1993.

Utsman, Husaini. Manajemen Teori, Praktik, Dan Riset Pendidikan. Jakarta: Bumi Aksara, 2009. 